\title{
Introduction to History, Memory, and the Making of Character in Roth's Fiction
}

\author{
Victoria Aarons \\ Trinity University \\ Gustavo Sánchez-Canales \\ Atonóma University Madrid
}

Follow this and additional works at: https://docs.lib.purdue.edu/clcweb

C.

Part of the American Studies Commons, and the Jewish Studies Commons

Dedicated to the dissemination of scholarly and professional information, Purdue University Press selects, develops, and distributes quality resources in several key subject areas for which its parent university is famous, including business, technology, health, veterinary medicine, and other selected disciplines in the humanities and sciences.

CLCWeb: Comparative Literature and Culture, the peer-reviewed, full-text, and open-access learned journal in the humanities and social sciences, publishes new scholarship following tenets of the discipline of comparative literature and the field of cultural studies designated as "comparative cultural studies." Publications in the journal are indexed in the Annual Bibliography of English Language and Literature (Chadwyck-Healey), the Arts and Humanities Citation Index (Thomson Reuters ISI), the Humanities Index (Wilson), Humanities International Complete (EBSCO), the International Bibliography of the Modern Language Association of America, and Scopus (Elsevier). The journal is affiliated with the Purdue University Press monograph series of Books in Comparative Cultural Studies. Contact:<clcweb@purdue.edu>

\section{Recommended Citation}

Aarons, Victoria; and Sánchez-Canales, Gustavo. "Introduction to History, Memory, and the Making of Character in Roth's Fiction." CLCWeb: Comparative Literature and Culture 16.2 (2014): <https://doi.org/10.7771/1481-4374.2403>

The above text, published by Purdue University Press (P) Purdue University, has been downloaded 520 times as of 05/ $07 / 20$.

This document has been made available through Purdue e-Pubs, a service of the Purdue University Libraries. Please contact epubs@purdue.edu for additional information.

This is an Open Access journal. This means that it uses a funding model that does not charge readers or their institutions for access. Readers may freely read, download, copy, distribute, print, search, or link to the full texts of articles. This journal is covered under the CC BY-NC-ND license. 


\section{PURDUE}

UNIVERSITY PRESS <http://www.thepress. purdue.edu>

\section{CLCWeb: Comparative Literature and Culture}

ISSN 1481-4374 <http://docs.lib.purdue.edu/clcweb> Purdue University Press (CPurdue University

CLCWeb: Comparative Literature and Culture, the peer-reviewed, full-text, and open-access learned journal in the humanities and social sciences, publishes new scholarship following tenets of the discipline of comparative literature and the field of cultural studies designated as "comparative cultural studies." In addition to the publication of articles, the journal publishes review articles of scholarly books and publishes research material in its Library Series. Publications in the journal are indexed in the Annual Bibliography of English Language and Literature (Chadwyck-Healey), the Arts and Humanities Citation Index (Thomson Reuters ISI), the Humanities Index (Wilson), Humanities International Complete (EBSCO), the International Bibliography of the Modern Language Association of America, and Scopus (Elsevier). The journal is affiliated with the Purdue University Press monograph series of Books in Comparative Cultural Studies. Contact: <clcweb@purdue.edu>

Volume 16 Issue 2 (June 2014) Article 1 Victoria Aarons and Gustavo Sánchez-Canales, "Introduction to History, Memory, and the Making of Character in Roth's Fiction" <http://docs.lib.purdue.edu/clcweb/vol16/iss2/1>

Contents of CLCWeb: Comparative Literature and Culture 16.2 (2014) Thematic Issue History, Memory, and the Making of Character in Roth's Fiction Ed. Gustavo Sánchez-Canales and Victoria Aarons

<http://docs.lib.purdue.edu/clcweb/vol16/iss2/1> 
Victoria Aarons and Gustavo Sánchez-Canales,

"Introduction to History, Memory, and the Making of Character in Roth's Fiction"

CLCWeb: Comparative Literature and Culture 16.2 (2014): <http://docs.lib.purdue.edu/clcweb/vol16/iss2/1>

Thematic Issue History, Memory, and the Making of Character in Roth's Fiction. Ed. Gustavo Sánchez-Canales and Victoria Aarons

\section{Introduction to History, Memory, and the Making of Character in Roth's Fiction}

\section{Victoria AARONS and Gustavo SÁNCHEZ-CANALES}

After over half a century of prolific and distinguished literary productivity, Philip Roth remains the voice of US-American cultural, intellectual, and literary conscience. Roth's fiction with the initial publication of Goodbye, Columbus and Other Stories in 1959 through his self-proclaimed final 2010 novel, Nemesis, reflects the dynamically changing landscape of US-American thought and character during the confusions and restless years from post-war prosperity and capricious self-reckoning through the first decade of a new and newly disposed millennium. Roth's fictive voice is the voice of a US-America trying to discover, recover, and reinvent itself. And the landscape of Roth's fiction is irreducibly and essentially US-American. In many ways, Roth's fictional worlds could take place nowhere else but in the United States. As Roth acknowledged in a 1981 interview with Alain Finkielkraut, the United States "is the place I know best in the world. It's the only place I know in the world. My consciousness and my language were shaped by America. I'm an American writer in ways that a plumber isn't an American plumber or a miner an American miner or a cardiologist an American cardiologist. Rather, what the heart is to the cardiologist, the coal to the miner, the kitchen sink to the plumber, America is to me" (128). In other words, the U.S. is the stuff and substance, the fabric and the fabrication of Roth's imaginative enterprise. His language and consciousness were formed by the U.S., by a country and culture contending with the radical changes of its century. To this end, Roth's voice is decidedly the voice of the urban, intellectual US-American writer coming of age in the late 1950s-early 1960s. Defined by an "America"-rich ethos of linguistic roguishness and the expansive certainty in the defining powers of both the unimpeded imagination and the supple plentitude of words, Roth's fictive presence emerged into the American literary stream shaped, in the words of his cunningly persistent character Nathan Zuckerman, by an "identity ... formed by the terrifying power of an imagination richer with reality than [one's] own" (The Counterlife 163-64). Yet the burgeoning, expansive streets of Roth's early, immigrant-infused US-America came to create in his literary project the fertile grounds for the imaginative re-fashioning of lives and the ironic assessment of the seemingly limitless capacity for human ingenuity and self-invention.

The imaginative capital from which Roth artfully draws is the urban U.S., its neighborhoods, its modes of escape, its history. Resembling his occasional doppelganger, Nathan Zuckerman-although who resembles whom is the source of bemused ventriloquism in much of Roth's fiction-Roth has his artful alter ego affirm in something of a parody of Roth's own beginnings:

My landscape ... was industrial, immigrant America - Newark where I'd been raised, Chicago where I'd been educated, and New York where I was living in a basement apartment on a Lower East Side street among poor Ukrainians and Puerto Ricans. My sacred text wasn't the Bible but novels translated from Russian, German, and French into the language in which I was beginning to write and publish my own fiction ... the jumpy beat of American English was what excited me ... I was the American-born grandson of simple Galician tradesmen who, at the end of the last century, had on their own reached the same prophetic conclusion as Theodor Herzl-that there was no future for them in Christian Europe, that they couldn't go on being themselves there without inciting to violence ominous forces against which they hadn't the slightest means of defense. (The Counterlife 58-59)

It is in the U.S. that history is in the remaking for Jews. If the U.S. provides the language and landscape of Roth's literary enterprise, then the upwardly mobile ascension of Jewish immigrants provides the resonant and bountiful disposition for the making of character, characters whose history and comportment deliver plentiful material for the assessment, calculation, and measurement of US-American life for and as seen through the eyes of U.S.-born and U.S.-made Jews.

For Roth can no more choose to be a US-American writer than a US-American Jew:

I was born into the situation of being a Jew, and it did not take me long to be aware of its ramifications ... I lived in a predominantly Jewish neighborhood and attended public schools where about 90 percent of the pupils and the teachers were Jewish. To live in an ethnic or cultural enclave like this wasn't unusual for an urban American child of my generation ... Newark ... until the late fifties ... was demographically divided up like any number of American industrial cities that had been heavily settled in the late nineteenth and early twentieth centuries by waves of immigration ... As soon as they could climb out of the slums where most of them began in America, more or less penniless, the immigrants formed neighborhoods within the cities where they could have the comfort and security of the familiar while undergoing the arduous transformations of a new way of life. (Roth qtd. in Finkielkraut 125) 
Victoria Aarons and Gustavo Sánchez-Canales,

For Roth, the U.S. began as Jewish America, the language and life infused with the sounds of Jewish history, memory, and character. If, as Nathan Zuckerman insists, "Jews ... are to history what Eskimos are to snow," then America, for Roth's host of characters, is one more step in the diasporic shuffling of self-reinvention with history always at its back (The Counterlife 368). As Roth explains:

I had simultaneously been surrounded from birth with a definition of the Jew of such stunning emotional and historical proportions that I couldn't but be enveloped by it, contrary though it was to my own experience. This was the definition of the Jew as sufferer, the Jew as an object of ridicule, disgust, scorn, contempt, derision, of every heinous form of persecution and brutality, including murder. If the definition was not supported by my own experience, it surely was by the experience of my grandparents and their forebears, and by the experience of our European contemporaries. The disparity between this tragic dimension of Jewish life in Europe and the actualities of our daily lives as Jews in New Jersey was something that I had to puzzle over myself, and indeed, it was in the vast discrepancy between the two Jewish conditions that I found the terrain for my first stories. (Roth qtd. in Finkielkraut 125-26)

For Roth, then, the "Jewish condition" of being the object of persecution and the subject of success, the duality of being at once dispossessed and at the same time possessed of the means of advantage and fortune-a condition balanced in the intersection of the past and the future-serves both as a portrait of a character type and as a metonymic depiction of the very character of the United States as a place of self-fashioning and defiant survival, whose own history, still in its adolescence, is both defining and of its own making. Roth expands and transforms this conflicting, quarreling, and contradictory definition of the Jewish condition in his fiction through his characteristically ironic, critical, and rebellious assessment, but mostly through the subtleties, the intricacies, the brilliances of language, the written word a measure of inspired, ventriloquistic, artful masquerade, "the art of impersonation," which is, after all, as Roth admits, "the fundamental novelistic gift" (Lee and Roth 143).

For Roth, the United States itself becomes, not surprisingly, his favorite character. Rife with absurdities, with fictions difficult to invent, the U.S. is a tough contender for the novelist's invention. There is a kind of preposterous absurdity, almost unbelievability, to US-America's condition, a malady of disorder and confusion unmatched by the imagination. As he puts it in the essay "Writing American Fiction": "the American writer in the middle of the twentieth century has his hands full in trying to understand, describe, and then make credible much of American reality. It stupefies, it sickens, it infuriates, and finally it is even a kind of embarrassment to one's one meager imagination. The actuality is continually outdoing our talents, and the culture tosses up figures almost daily that are the envy of any novelist" (176; emphasis in the original). Yet, for Roth, the U.S. becomes the "patient," its landscape the perfect center for the acting-out of transgressions, apprehensions, and countless obsessions in response to "the terror of the unforeseen" (The Plot 114).

Roth's fiction, thus, presents us with a diagnosis of a feverish U.S. where anxieties are played out in the neuroses of his characters, whose symptoms invariably, and not uncomically, are the source of the critical authorial eye. "How far back must you go," Roth's confused character Lou Epstein uneasily wonders, "to discover the beginning of trouble?" (Goodbye 208). Ever since the publication of the novella and early stories in Goodbye, Columbus and the ironically exacting assessment of the "making" of the US-American character for post-war Jews in their uneasy, upward ascent from the gritty, urban streets of Newark to the Edenic, pastoral myth of genteel and prosperous U.S., Roth has cast his censoring eye on the anxious convolutions and insecurities of US-American self-fashioning. In the headlong, unrestrained, frontal embrace of a hard-won mimicry of those polished, homogenized accommodations of Waspish, gentile habits and requirements, Roth shows the making of character to be in the often misguided, expansive self-interest of its players, its sufferers and precarious victors. From Neil Klugman's initial escape from Newark's working-class, claustrophobic, immigrant enclave-its proffered fruits, literal and figurative, always just beyond reach-to Bucky Cantor's flight from poliostricken Newark and its reactive, viral fear and regression, Roth's characters have been in flight, a hoped-for escape not only from their physical confines, but from themselves, from the selves bequeathed to them. Their exodus from urban U.S. cityscapes to rural and suburban expansiveness and promise-"no pogroms ... the world ... at last a place for ... Jewish families"-constitutes a kind of return narrative, a return, that is, back again, either literally or in the imagination to the place of one's 
making as well as one's undoing ("Eli, the Fanatic" 277, 280). The diagnoses-the neuroses, phobias, and ironies-played out on the literary pages of Roth's fiction stand as sentry to an uneasy mirror of the failures and foibles, the insecurities and disquietudes, the propensities and fabrications, the deceits and fantasizing of an unrestrained and deafening age of anxious self-fashioning in the U.S. The United States is, for Roth, the source of both immeasurable, unbounded promise and achievement and diasporic instability and the uneasy, backward glance over both US-American and Jewish histories.

Thus, for Roth, history and memory are the twin motivating conceits that attend to and adjudicate character. Roth's characters are "made" with history-both its successes and failures-guiding and censoring their comportment and disposition. The trajectory of Roth's fiction is, in retrospect, a history of US-American anxieties, fantasies, obsessions, and the kaleidoscopic-and often myopic-attempts to remake itself, to refashion itself, not unlike the ways in which his characters conjure for themselves a parade of biographies. Thus making character is a matter of making and reinventing history, individual histories in the face of the menacing certainties of history at work:

Making fake biography, false history, concocting a half-imaginary existence out of the actual drama of my life is my life. There has to be some pleasure in this job, and that's it. To go around in disguise. To act a character. To pass oneself off as what one is not. To pretend. The sly and cunning masquerade. Think of the ventriloguist. He speaks so that his voice appears to proceed from someone at a distance from himself. But if he weren't in your line of vision you'd get no pleasure from his art at all. His art consists of being present and absent; he's most himself by simultaneously being someone else, neither of whom he "is" once the curtain is down. You don't necessarily, as a writer, have to abandon your biography completely to engage in an act of impersonation ... You distort it, caricature it, parody it, you torture and subvert it, you exploit it - all to give the biography that dimension that will excite your verbal life ... It's amazing what lies people can sustain behind the mask of their real faces ... Make-believe can take the subtlest forms. (Lee and Roth 144-45)

The novelist is, for Roth, "a pretender by profession," an inventor who must play different parts: character(s) and puppeteer (Lee and Roth 144). Throughout his long trajectory of literary productivity, Roth as novelist creates and recreates his authorial presence as superego, the punishing, admonishing voice of conscience. To his superego, his characters assume the uncomfortable roles of ego and id as they attempt to elude, navigate, deceive, and appease the punitive, censoring author.

As Roth has said, "At best writers change the way readers read" (Lee and Roth 170; emphasis in the original). For the better part of the past century, Roth has posed for readers a view of the U.S. and of themselves that is unrelenting in its honesty and perspicacity. In changing the way we read, Roth has changed the ways in which we view the world in which we live. In doing so, Roth forces both the backward glance and the inward gaze. Like Neil Klugman, one is compelled to see his or her "reflection," to have "looked ... in the mirror," and, as Roth's prototype uncomfortably but not entirely unwelcomingly achieves, "looked hard at the image of me, at that darkening of the glass, and then my gaze pushed through it" (Goodbye 136). Philip Roth has avowed that he is "finished ... done with fiction. I don't want to read any more of it, write any more of it, I don't even want to talk about it anymore. I've given my life to the novel. I've studied it, I've taught it, I've written it, and I've read it ... It's enough!" (Kaprielian <http://www.theparisreview.org/blog/2012/11/13/in-which-philip-rothannounces-his-retirement-in-english/>). To Roth's pronouncement we can only respond by aligning ourselves with Henry Zuckerman, who, taken aback by his fate, insistently entreats, "and yet there must be more, there has to be more" (The Counterlife 18; emphasis in the original).

The studies presented in CLCWeb: Comparative Literature and Culture and devoted to Roth's literary preoccupation with history, memory, and the making of character demonstrate the evolution of the Rothian character from his early work to his most recent novels. In doing so, the essays that follow suggest the scope and depth of expression in Roth's oeuvre as well as the range of approaches his fiction inspires. The editors of this special thematic issue have loosely arranged the essays into three sections: 1) memory, 2) history, and 3) the making of character. While, as we suggest, these concerns are connected intricately, the one informing the others in complex ways, the studies are arranged to indicate the primary emphasis and direction taken by the authors toward Roth's fiction. We organized the articles as showing the ways in which memory opens itself up to history and how the subtleties and echoes of both memory and history lead to the making of character. The articles in History, Memory, and the Making of Character in Roth's Fiction, thus arranged, are as follows:

In "Roth's Graveyards, Narrative Desire, and 'Professional Competition with Death'" 
Victoria Aarons and Gustavo Sánchez-Canales,

"Introduction to History, Memory, and the Making of Character in Roth's Fiction"

CLCWeb: Comparative Literature and Culture 16.2 (2014): <http://docs.lib.purdue.edu/clcweb/vol16/iss2/1>

Thematic Issue History, Memory, and the Making of Character in Roth's Fiction. Ed. Gustavo Sánchez-Canales and Victoria Aarons

<http://docs.lib.purdue.edu/clcweb/vol16/iss2/2> Debra Shostak analyzes Philip Roth's 1954 short story "The Day It Snowed" and surveys a range of his books. Shostak offers a reading of Sabbath's Theater and Everyman to explore Roth's fictional forms and his conception of storytelling, elucidates how the traumatic knowledge of death at graveside initiates the psychoanalytic process of repression, repetition, remembering, and telling, and uncovers several motifs or formal strategies that appear when Roth deploys cemetery scenes: the linear plotting toward death is often embraced within circular narrative structures, the voice of the mother, dead or alive, presides over the protagonist's traumatic confrontation with mortality; and the narrative represents the battle waged between eros and thanatos. From the beginning of his career, Roth has sent his characters to meditate in graveyards or over coffins at crucial junctures such as narrative beginnings and endings. Drawing on psychoanalytic accounts of narrative desire, Shostak argues that Roth is preoccupied with the graveyard scene as a symbolic incitement to the compulsion that he calls in The Human Stain "professional competition with death."

In "Roth's Contribution to the Narrativization of Illness"

<http://docs.lib.purdue.edu/clcweb/vol16/iss2/3> Miriam Jaffe-Foger argues that Philip Roth's fiction represents him as an empath, a writer who prescribes for modern medicine a dose of humanity in listening to the pain of others. Using Roth's The Anatomy Lesson, The Dying Animal, and Exit Ghost as primary source material in combination with theories from medical anthropology, Jaffe-Foger suggests that Roth is an inspiration for the field of narrative medicine. Jaffe-Foger examines the art in organizing narratives to tell these stories. Jaffe-Foger also argues against misogynist views of Roth as he represents woman's bodies, offering a modern reading of the relationship between illness and sexuality.

In "Reverse Anti-Semitism in the Fiction of Bellow and Roth"

<http://docs.lib.purdue.edu/clcweb/vol16/iss2/4> Jay L. Halio argues that anti-Semitism is a wellknown theme in much of Philip Roth's fiction, but what might be called reverse anti-Semitism-the active reaction by Jews who are subjected to anti-Semitism-is not as often discussed. It is not the same as philo-Semitism, which takes a different form entirely. Since Roth was an admirer of Saul Bellow, this essay begins by considering reverse anti-Semitism in Bellow's early novel The Victim (1947). In it the protagonist, Asa Leventhal, is accused by a character named Allbee of costing him his job and his subsequent downfall because of some anti-Semitic remarks he once made involving a friend of Leventhal's. According to Allbee, Leventhal deliberately provoked Allbee's boss in such a way that he blamed Allbee for the altercation, which led to his being fired. To clarify more fully the nature of reverse anti-Semitism, Shakespeare's The Merchant of Venice is invoked to show how the Jewish money-lender Shylock takes revenge against his Christian antagonist, the Venetian merchant Antonio, who has repeatedly scorned him in many ways. Finally, the essay focuses on Roth's treatment of reverse anti-Semitism in Portnoy's Complaint where Alexander's actions with gentile women he seduces is prompted at least in part by feelings of revenge for the anti-Semitism his father has experienced over many years. Another form of reverse anti-Semitism in Roth's later novel, Operation Shylock, is also discussed.

In "Akedah, the Holocaust, and the Limits of the Law in Roth's 'Eli, the Fanatic'"

<http://docs.lib.purdue.edu/clcweb/vol16/iss2/5> Aimee L. Pozorski argues that Philip Roth's 1957 short story dramatizes the tension between the law on the one hand and the philosophy of ethics on the other hand, with the story's protagonist ultimately choosing ethics as evidenced by his identification with a displaced Hasidic Jew near the story's end. In reading the story through the inter-textual references to the Genesis story of the Akedah, Pozorski discusses the limits of the law in the face of vulnerable children and within the context of the history of the Holocaust.

In "Jewish History, US-American Fictions, and 'Soul-Battering' in Roth's 'Conversion of the Jews'" <http://docs.lib.purdue.edu/clcweb/vol16/iss2/6> Sandor Goodhart discusses Philip Roth's story in which an innocent question raised in a Hebrew school discussion in the early 1950 s gets out of control. It leads the student into a screaming fight with his Rabbi, which propels the child into a confrontation with his mother, which in turn leads to a second violent act. The episode leads, finally, to a rooftop exchange over the synagogue where the child's thought of escape is suddenly converted into the desire to jump. Goodhart argues that the key to Roth's "Conversion of the Jews" may be to say that 
Victoria Aarons and Gustavo Sánchez-Canales,

"Introduction to History, Memory, and the Making of Character in Roth's Fiction"

CLCWeb: Comparative Literature and Culture 16.2 (2014): <http://docs.lib.purdue.edu/clcweb/vol16/iss2/1>

Thematic Issue History, Memory, and the Making of Character in Roth's Fiction. Ed. Gustavo Sánchez-Canales and Victoria Aarons

after all the skewed communications the acts of conversion in which they all participate render them not less Jewish than before, but more so. Turning against their own religious practice in a time of crisis when a human life is at stake endorsing in an unqualified and unmitigated way, the "boy on the roof" is the practice of anti-idolatry itself.

In "The Perils of Desire in Roth's Early Fiction" <http://docs.lib.purdue.edu/clcweb/vol16/iss2/7> Victoria Aarons posits that Philip Roth's first collection of stories Goodbye, Columbus is the prototype for a host of characters who emerge throughout his oeuvre: characters who are engaged, as the inveterate Nathan Zuckerman insists, in "an exchange of existences" abandoning willingly "the artificial fiction" of an inherent, essential self." From the stories in Goodbye, Columbus to the "final" novels comprising the Nemesis tetralogy, Roth's characters perform a spectacle of selves engaged in the making of character. The making of character in Roth's fiction appears in two ways: 1) the developing of protagonists who emerge throughout the trajectory of Roth's extensive literary career and 2) each protagonist's individual psychic project of making himself his own favorite character. For Roth, character is all about motive, those oppositional and ambivalent impulses which drive people to perform acts of desperate self-assertion, all part of the masquerade of self-reinvention.

In "European Literary Tradition in Roth's Kepesh Trilogy"

<http://docs.lib.purdue.edu/clcweb/vol16/iss2/8> Gustavo Sánchez-Canales discusses the significance of European literature in Philip Roth's novels. Sánchez-Canales analyses the influence of Nikolai Gogol's "The Nose" and Franz Kafka's "The Metamorphosis" on Roth's The Breast, and in Roth's The Professor of Desire of Anton Chekhov's tales and Franz Kafka's "A Hunger Artist" and The Castle. Further, Sánchez-Canales elaborates on the impact of Thomas Mann's Death in Venice and W.B. Yeats's poem "Sailing to Byzantium" on Roth's The Dying Animal.

In "Philip Roth, Henry Roth, and the History of the Jews"

<http://docs.lib.purdue.edu/clcweb/vol16/iss2/9> Timothy Parrish argues that while Roth's status as a Jewish American writer has been a pressing issue since his career began and that while in recent scholarship Roth's achievement as a US-American writer is stressed, the durability of Roth's work depends more on its implied submission to a Jewish tradition. From "The Conversion of the Jews" (1959) to Nemesis (2010), his characters challenge endlessly the ethical and moral constructs of their Jewish community to acknowledge the fact that they exist inside of it. One might choose any of Roth's late works to explore this claim, but Exit Ghost (2007) is compelling in particular because it asks us to consider Roth's career in the context of the life and work of his critically overlooked predecessor and literary counter-ego, Henry Roth.

In "Roth's Fiction from Nemesis to Nemesis" <http://docs.lib.purdue.edu/clcweb/vol16/iss2/10> Emily Budick shows Roth's Nemesis to be the culminating work of a career in which one nemesis or another has afflicted almost all of his protagonists. Nemesis in Roth's career, however, referred less to a cosmic condition, as it does in the book of that title, than to a local enemy. In Nemesis Roth explores the relationship between fate and fatality in human life. And he makes his peace with human frailty and death.

In "Literary Adaptations of James in Roth's, Ozick's, and Franzen's Work"

<http://docs.lib.purdue.edu/clcweb/vol16/iss2/11> John Carlos Rowe posits that Henry James continues to exert a powerful influence on contemporary writers. Given the dramatic social, economic, and political changes from modern to postmodern eras, his continuing influence requires explanation. Rowe considers three US-American novelists-Philip Roth, Cynthia Ozick, and Jonathan Franzen-who are influenced by James and presents an interpretation of James's continuing impact. Despite James's reputation as a cosmopolitan modern who influenced global literature in significant ways, US-American writers attempt to "Americanize" him. Their effort expresses the problem of contemporary USAmerican literary practice and its professional interpretation: as national literatures lose their boundaries, authors, critics, and scholars alike face the problem of understanding their work in relationship to communities which exceed conventional geopolitical and cultural national forms. James's transnational experience and work anticipate a crisis of representation and interpretation we are just now beginning to address.

In "Roth's Humorous Art of Ghost Writing" <http://docs.lib.purdue.edu/clcweb/vol16/iss2/12> Paule Lévy analyses Philip Roth's Exit Ghost, the last novel featuring Nathan Zuckerman, in which 
Victoria Aarons and Gustavo Sánchez-Canales,

"Introduction to History, Memory, and the Making of Character in Roth's Fiction"

CLCWeb: Comparative Literature and Culture 16.2 (2014): <http://docs.lib.purdue.edu/clcweb/vol16/iss2/1>

page 7 of 8

Thematic Issue History, Memory, and the Making of Character in Roth's Fiction. Ed. Gustavo Sánchez-Canales and Victoria Aarons

Roth reassesses his favorite alter ego's itinerary while exploring the troubled relation between writing and aging. Lévy considers Exit Ghost as an ironic sequel to The Ghost Writer and posits that in the light of Derrida's theories of writing and "hauntology" the central motives of ghosts and "spectrality" in the novel are a means for Roth to reflect anew on the ambiguous relation between autobiography and fiction. Lévy asks whether Exit Ghost should be read as an expression of Roth's pessimism, as a "ghost novel" predicting its own disappearance as a cultural artifact, or whether it should be read as an assertion of Roth's indefatigable vitality and faith in the priceless value of art. Lévy's study is a textual analysis and a close examination of the dialogic links between the storyline and its haunting multifarious intertext in Joseph Conrad's partly autobiographical novel The Shadow Line, a central reference in Exit Ghost.

In "Roth's The Counterlife and the Negotiation of Reality and Fiction"

<http://docs.lib.purdue.edu/clcweb/vol16/iss2/13> Pia Masiero analyzes some aspects of the readers' negotiations of Phillip Roth's 1986 novel. Masiero shows how Roth in the novel's first chapter "Basel" anatomizes what follows and provides the rules of pertinence which guide the text and the keys to interpret its meaning. Masiero argues that the effects of perspective created by the employment of third-person narration and contra-punctual simultaneous narratives prepare readers for the metafictional choices they encounter in the final chapters of the book. With her analysis, Masiero posits that the novel turns out to be a journey in Nathan Zuckerman's writerly mind and a window on how our own minds work.

History, Memory, and the Making of Character in Roth's Fiction contains a "Bibliography for the Study of Phillip Roth's Work" compiled by Gustavo Sánchez-Canales and Victoria Aarons

<http://docs.lib.purdue.edu/clcweb/vol16/iss2/14>.

We thank the editor of CLCWeb: Comparative Literature and Culture Steven Tötösy de Zepetnek for the opportunity to publish new studies about one of US-America's most prominent writers and hope that the articles in History, Memory, and the Making of Character in Roth's Fiction would elicit interest and further studies of Roth's work world wide.

\section{Works Cited}

Aarons, Victoria. "The Perils of Desire in Roth's Early Fiction." CLCWeb: Comparative Literature and Culture 16.2 (2014): <http://docs.lib.purdue.edu/clcweb/vol16/iss2/7>.

Aarons, Victoria, and Gustavo Sánchez-Canales. "Introduction to History, Memory, and the Making of Character in Roth's Fiction." CLCWeb: Comparative Literature and Culture 16.2 (2014): $<$ http://docs.lib.purdue.edu/clcweb/vol16/iss2/1>.

Budick, Emily. "Roth's Fiction from Nemesis to Nemesis." CLCWeb: Comparative Literature and Culture 16.2 (2014): <http://docs.lib.purdue.edu/clcweb/vol16/iss2/10>.

Finkielkraut, Alain. "Interview with Le Nouvel Observateur"." 1981. Reading Myself and Others. By Philip Roth. New York: Penguin, 1985. 115-28.

Goodhart, Sandor. "Jewish History, American Fictions, and 'Soul-Battering' in Roth's 'Conversion of the Jews.'" CLCWeb: Comparative Literature and Culture 16.2 (2014): <http://docs.lib.purdue.edu/clcweb/vol16/iss2/6>.

Halio, Jay L. "Reverse Anti-Semitism in the Fiction of Bellow and Roth." CLCWeb: Comparative Literature and Culture 16.2 (2014): <http://docs.lib.purdue.edu/clcweb/vol16/iss2/4>.

Jaffe-Foger, Miriam. "Roth's Contribution to the Narrativization of Illness." CLCWeb: Comparative Literature and Culture 16.2 (2014): <http://docs.lib.purdue.edu/clcweb/vol16/iss2/3>.

Kaprielian, Nelly. "In What Philip Roth Announces His Retirement." The Paris Review 13 (2012): <http://www.theparisreview.org/blog/2012/11/13/in-which-philip-roth-announces-his-retirement-inenglish/>.

Lee, Hermione, and Philip Roth. "Interview with The Paris Review." The Paris Review 93 (1984): 214-47.

Lévy, Paule. "Roth's Humorous Art of Ghost Writing." CLCWeb: Comparative Literature and Culture 16.2 (2014): <http://docs.lib.purdue.edu/clcweb/vol16/iss2/12>.

Masiero, Pia. "The Counterlife: Negotiating Reality and Fiction." CLCWeb: Comparative Literature and Culture 16.2 (2014): <http://docs.lib.purdue.edu/clcweb/vol16/iss2/13>.

Parrish, Timothy. "Philip Roth, Henry Roth, and the History of the Jews." CLCWeb: Comparative Literature and Culture 16.2 (2014): <http://docs.lib.purdue.edu/clcweb/vol16/iss2/9>.

Pozorski, Aimee. "Akedah, the Holocaust, and the Limits of the Law in Roth's 'Eli, the Fanatic.'" CLCWeb: Comparative Literature and Culture 16.2 (2014): <http://docs.lib.purdue.edu/clcweb/vol16/iss2/5>.

Roth, Philip. "Eli, the Fanatic." 1957. Goodbye, Columbus and Five Short Stories. 1959. New York: Vintage, 1993. 247-98.

Roth, Philip. Goodbye, Columbus and Five Short Stories. Boston: Houghton Mifflin, 1959.

Roth, Philip. Nemesis. New York: Houghton Mifflin, 2010.

Roth, Philip. The Counterlife. New York: Farrar, Straus and Giroux, 1986.

Roth, Philip. The Plot Against America: A Novel. Boston: Houghton Mifflin, 2004. 


\begin{abstract}
Victoria Aarons and Gustavo Sánchez-Canales,
"Introduction to History, Memory, and the Making of Character in Roth's Fiction"

CLCWeb: Comparative Literature and Culture 16.2 (2014): <http://docs.lib.purdue.edu/clcweb/vol16/iss2/1>

Thematic Issue History, Memory, and the Making of Character in Roth's Fiction. Ed. Gustavo Sánchez-Canales and Victoria Aarons

Rowe, John Carlos. "Recent Literary Adaptations of James." CLCWeb: Comparative Literature and Culture 16.2 (2014): <http://docs.lib.purdue.edu/clcweb/vol16/iss2/11>.

Sánchez-Canales, Gustavo. "European Literary Tradition in Roth's Kepesh Trilogy." CLCWeb: Comparative Literature and Culture 16.2 (2014) <http://docs.lib.purdue.edu/clcweb/vol16/iss2/8>.

Sánchez-Canales, Gustavo, and Victoria Aarons. "A Selected Bibliography for Roth's Works." CLCWeb: Comparative Literature and Culture 16.2 (2014): <http://docs.lib.purdue.edu/clcweb/vol16/iss2/14> .

Shostak, Debra. "Roth's Graveyards, Narrative Desire, and 'Professional Competition with Death'." CLCWeb: Comparative Literature and Culture 16.2 (2014): <http://docs.lib.purdue.edu/clcweb/vol16/iss2/2>.

Author's profile: Victoria Aarons teaches US-American Jewish literature and Holocaust literature at Trinity University. In addition to numerous articles, her book publications include A Measure of Memory: Storytelling and Identity in American Jewish Fiction (1996), What Happened to Abraham? Reinventing the Covenant in American Jewish Fiction (2005), The New Diaspora: The Changing Landscape of American Jewish Fiction (2014), and ThirdGeneration Holocaust Representation: Trauma, History, and Memory (forthcoming 2015).

E-mail: <vaarons@trinity.edu>

Author's profile: Gustavo Sánchez Canales teaches English-language literatures at Autónoma University Madrid. His interests in scholarship include contemporary Jewish American fiction, Holocaust literature, comparative literature, and literary theory. He has published numerous articles, book chapters, and book reviews on the work of authors including Philip Roth, Saul Bellow, Bernard Malamud, Chaim Potok, Cynthia Ozick, Allegra Goodman, Rebecca Goldman, Jonathan Safran Foer, and Michael Chabon. E-mail: <gustavo.sanchez@uam.es>
\end{abstract}

